\title{
Implementation of Liability Rights Execution at Bank Bri Syari'ah Mataram Branch
}

\author{
Suciati Rizki Adila ${ }^{1} \quad$ Hirsanuddin $^{2} \quad$ Muhaimin $^{2}$ \\ 1.Graduate Program Student in Notary, Faculty of Law, Mataram University, Indonesia \\ 2.Lecturer of Faculty of Law, Mataram University, Indonesia
}

\begin{abstract}
This study aims to analyze and explain the regulatory mechanism and execution of mortgage rights at the Mataram Branch of the BRI Syari'ah Bank and the competence of the West Lombok Giri Menang Religious Court regarding the settlement of mortgage execution disputes at the Mataram Branch of BRI Syari'ah Bank. This research method is a normative-empirical legal research with a statutory approach, a conceptual approach and a sociological approach. From the research results obtained the first results, namely the arrangement and execution of mortgage rights at the Bank BRI Syari'ah Mataram Branch based on Article 6 Jo. Article 20 of Law Number 4 of 1996 concerning Mortgage Rights by using the Parate Executie. The Execution Parate in Law Number 4 of 1996 concerning Mortgage Rights is aimed at providing convenience to the Bank BRI Syari'ah Mataram Branch as the Creditor in executing the object of the mortgage in order to get full repayment of the debt if the debtor is in default. Second, the competence of the West Lombok Giri Menang Religious Court in terms of resolving mortgage execution disputes at the Mataram Branch of the BRI Syari'ah Bank has become the absolute competence (authority) of the Giri Menang Religious Court as regulated in Law Number 3 of 2006 concerning Amendments to the Law. -Law Number 7 of 1989 concerning Religious Courts and Article 55 of Law Number 21 of 2008 concerning Syari'ah Banking, as long as this is contained in the contract and the settlement mechanism applies the principles of shari'ah.
\end{abstract}

Keywords: execution, mortgage, Bank BRI Syariah Mataram Branch.

DOI: $10.7176 / \mathrm{JLPG} / 107-04$

Publication date:March $31^{\text {st }} 2021$

\section{INTRODUCTION}

Syari'ah Banking Institutions as business entities that play an important role in development activities through Bank Syari'ah, namely institutions that are active and also credible in supporting national development that can influence the world economy. National development to improve the standard of life for a just and prosperous society as stated in Pancasila and the 1945 Constitution of the Republic of Indonesia. Where, the function of the Syari'ah Bank is such as collecting funds, channeling funds and providing services in the spirit of the shari'ah economy. Indonesian society. One of the business activities of Bank Syari'ah in terms of channeling funds is providing financing (murabahah) which is commonly referred to as credit in conventional banks.

Disbursing financing funds to customers or debtors who need it, of course, must be accompanied by conditions that can guarantee that there are no non-performing loans that harm Bank Syari'ah as a creditor. Bank Syari'ah provides financing if there is collateral (guarantee). Before providing financing, a creditor must know the ability and willingness of the debtor to return the financing funds on time, therefore the creditor needs to carry out several assessments in the financing application.

Among these assessments, one of them is Collateral, which is in the form of goods submitted by the debtor to the creditor as collateral (guarantee) against the refund of the financing he has received ${ }^{1}$ The importance of collateral in Bank Syari'ah financing is as a legal protection for the security of creditors in overcoming risks, namely so that there is certainty that the debtor will repay the loan. ${ }^{2}$ Article 1 paragraph (26) of Law Number 21 of 2008 concerning Islamic Banking states that collateral is additional collateral, ${ }^{3}$ both in the form of movable and immovable objects that the owner of the collateral gives to a Shari'ah Bank and / or Shari'ah Business Unit. in order to ensure the payment of the obligations of the customer receiving the facility in line with this in Article 1 paragraph (1) of Law Number 4 of 1996 concerning Mortgage Rights which states that the Land Rights and Objects Related to Land, hereinafter referred to as Mortgage Rights are Rights Collateral imposed on land rights as referred to in Law Number 5 of 1960 concerning Basic Agrarian Principles. ${ }^{4}$

However, all shari'ah economic activities do not always run well in practice, but in it there is a potential conflict between related parties that may occur during the implementation of an agreement (contract) or conflict

\footnotetext{
${ }^{1}$ Adrian Sutedi, Hukum Hak Tanggungan, Sinar Grafika, Jakarta, 2010, hlm. 14.

${ }^{2}$ Nurma Khusna Khanifa, “Jaminan Akad Murabahah di Lembaga Keungan Syariah Kajian Hukum Perdata”, Az-Zarqa', Volume 7 No. 2 , Desember 2015, Purwokerto, hlm.264.

${ }^{3}$ Indonesia, Undang-Undang Nomor 21 Tahun 2008 tentang Perbankan Syari'ah, (LN No. 182 Tahun 1998, TLN No. 3790), Pasal 1 ayat (26).

${ }^{4}$ Indonesia, Undang-Undang Nomor 4 Tahun 1996 Tentang Hak Tanggungan, (LN No. 104 Tahun 1960, TLN No. 2043), Pasal 1 ayat (1).
} 
in terms of interpreting the contents of an agreement (contract). ). In syari'ah banking practice, a conflict that may occur is that there are customers who experience credit problems when carrying out their obligations. The same thing happened at BRI Syari'ah Bank Mataram branch.

If there is a non-performing loan at Bank Syari'ah, especially BRI Syari'ah Bank Mataram, then the first step that must be taken by Bank Syari'ah based on Fatwa DSN ${ }^{1}$ Number 48 / DSN-MUI / II / 2005 is to carry out a financing restructuring. ${ }^{2}$ Financing restructuring as described in Article 1 paragraph (7) of Bank Indonesia Regulation Number 10/18 / PBI / 2008 concerning Restructuring of Financing for Syari'ah Banks and Syari'ah Business Units in order to assist customers in completing their obligations, including through: Scheduling Rescheduling, Reconditioning and Restructuring. ${ }^{3}$ However, if this initial step has been carried out and does not produce results or the customer has not yet completed his obligations, the creditor or the Syari'ah Bank can execute the object of the customer who has defaulted on the security rights object of the customer.

There are several steps that can be taken by creditors in carrying out the execution of mortgage rights, one of which is the Parate Executie through the State Wealth and Auction Service Office based on Article 6 of the Mortgage Law which states that if the debtor fails to promise, the first Mortgage holder has the right to sell the object of the Right. Dependent on their own power through a public auction and collect the receivables from the proceeds from the sale.

However, the execution of mortgage rights through a public auction cannot be carried out if there is a lawsuit from the debtor or third party other than the debtor against the object of the coverage right in question. If this condition occurs, the execution will be carried out based on the executorial title of the Mortgage Certificate which requires a stipulation / fiat execution. Requests for execution are made by the judiciary if the mortgage holder adheres to the syari'ah system, the tender request is made at the Religious Court. ${ }^{4}$ This caused the absolute authority of the Religious Courts to expand with the enactment of Law Number 3 of 2006 as the First Amendment to Law Number 7 of 1989 concerning the Religious Courts, namely regarding the authority to adjudicate sharia economic disputes in this case the execution of mortgage rights at Bank Syari 'Ah. Meanwhile, regulations like this are not in accordance with the parate executie concept stipulated in Article 6 Jo. Article 20 paragraph (1) of Law Number 4 of 1996 concerning Mortgage Rights to Land and Objects Related to Land and Article 1178 paragraph (2) of the Civil Code where the right holder does not need to seek prior approval from the guarantor of the mortgage right ${ }^{5}$ Right holders do not need to request a court order if they are going to execute an object that is encumbered with mortgage rights when the debtor fails to promise.

Based on the review of the legal rules above and the implementation of the execution of the mortgage rights based on Article 6 of the Mortgage Law, the Syari'ah Bank can not always be used as an alternative to solving non-performing loans which are guaranteed by mortgage rights due to problem factors that lead to the execution process of mortgage rights. it cannot work as it should. These problem factors include the incompatibility of the legal substance of the Mortgage Rights Law which regulates the execution of the mortgage itself, the actions and paradigms of law enforcement officials, as well as the existing legal culture in society. These problem factors in the end make Islamic banking institutions unable to carry out the execution of mortgage rights easily in accordance with the formation of the Mortgage Rights Law. Syari'ah banks will suffer more losses if nonperforming loans cannot be resolved in a relatively fast period of time, so that according to the author there is a gap between das sollen and das sein.

Based on the aforementioned background, the purpose of this study is to find out the implementation mechanism for the execution of mortgage rights at the Mataram Branch of the Bank BRI Syari'ah and the competence of the West Lombok Giri Menang Religious Court in terms of resolving mortgage execution disputes at Bank BRI Syari'ah Mataram Branch. Thus the purpose of this study is to analyze and explain the implementation mechanism for the execution of mortgage rights at the Mataram Branch of the Bank BRI Syari'ah and to analyze and explain the competence of the West Lombok Giri Menang Religious Court in terms of dispute settlement of mortgage execution rights at Bank BRI Syari'ah Mataram Branch.

\section{RESEARCH METHOD}

The research method used is normative-empirical legal research. With a research approach using a statutory approach (statute approach), a conceptual approach (conceptual) and a sociological approach. Types and sources

\footnotetext{
${ }^{1}$ Dewan Syariah Nasional (DSN) Majelis Ulama Indonesia (MUI) bahasa Arab : al-Ha 'iah al-Syar'iyyah al-Wathaniyyah-Majlis as-Ulama as-Indunisiyy atau National Sharia Board-Indonesian Council of Ulama, didirikan oleh MUI pada 10 Februari 1999 , dengan maksud untuk melaksanakan tugas MUI dalam menetapkan fatwa dan mengawasi penerapannya guna menumbuhkembangkan usaha bidang keuangan, bisnis, dan ekonomi syariah di Indonesia.

${ }^{2}$ Dewan Syari'ah Nasional MUI, Himpunan Dewan Syari'ah Nasional MUI, Nomor 10/18/DSN-MUI/II/2005 tentang Penjadwalan Kembali Tagihan Murabahah

${ }^{3}$ Faturrahman Djamil, Penyelesaian Pembiayaan Bermasalah di Bank Syariah, Sinar Grafik, Jakarta, 2012, hlm. 83.

${ }^{4}$ Indonesia, Peraturan Menteri Keuangan Republik Indonesia Nomor 27/PMK.06/2016 tentang Petunjuk Pelaksanaan Lelang, Berita Negara Republik Indonesia Tahun 2016 Nomor 270, Pasal 14 ayat (1), (2) dan ayat (3).

${ }^{5}$ Indonesia, Kitab Undang-Undang Hukum Perdata, (Stbl. 1847-23), Pasal 1178 ayat (2).
} 
of research data using secondary data and primary data. Research locations were in the Mataram branch of the BRI Syari'ah Bank and the Giri Menang Religious Court, West Lombok. Data collection techniques are using literature study, document study and interviews. The data analysis in this study used qualitative data analysis and concluded using the deductive method.

\section{DISCUSSION}

\section{A. IMPLEMENTATION OF LIABILITY RIGHTS EXECUTION AT MATARAM BRANCH SYARIAH} BANK BRI

The execution of Mortgage Rights is one of the efforts made by creditors, in this case, the Mataram Branch of the BRI Syari'ah Bank in order to rescue non-performing loans from debtors or customers who are in default. The term non-performing credit classification is a term commonly used to indicate credit collectibility classifications that describe the quality of the credit itself. ${ }^{1}$ The existence of non-performing loans in the world of Islamic banking is something that is very disturbing and threatens the sustainability of the business of Islamic banking institutions ${ }^{2}$

Before deciding whether a financing application can be accepted or rejected, Bank Syari'ah as a creditor takes the first step by analyzing the financing application submitted by a customer who is a debtor. ${ }^{3}$ The importance of conducting this analysis is to avoid the risk of possible bad credit (non-performing loans) ${ }^{4}$ Bank Indonesia through Bank Indonesia Regulation (PBI) Number 7/2 / PBI / 2005 Concerning Asset Quality Assessment for Commercial Banks, as last amended by PBI Number 11/2 / PBI / 2009, has determined credit quality based on an assessment factor consisting of prospects business, debtor performance and debtor's ability to pay. ${ }^{5}$

The assessment of the debtor's business prospects includes an assessment of the potential for business growth, market conditions and the debtor's position in competition, management quality and manpower problems. Assessment of debtor performance includes an assessment of components, namely profitability, capital structure, cash flow, and sensitivity to market risk. Meanwhile, the assessment of the debtor's ability to pay includes an assessment of the accuracy of principal and interest payments, availability and accuracy of debtor financial information, completeness of credit documentation, compliance with credit agreements. All of these assessment factors will determine the credit quality of the debtor and classify it into credit quality classifications, namely Current, Special Mention, Substandard, Doubtful and Bad Credit. ${ }^{6}$ This classification will make it easier for Syari'ah Bank, especially BRI Syari'ah Bank, Mataram Branch in classifying non-performing loans because it can be done automatically by the loan system used by Bank Syari'ah. So it can be concluded that a credit can be classified as a non-performing loan when it is included in the Substandard, Doubtful and Bad Credit categories which can be seen based on business prospects, debtor performance and the ability to pay the debtor. These are efforts that have been made by the NPF Bank BRI Syari'ah Mataram Branch Account Officer to ensure that the financing provided can be returned properly. However, in reality the risk of non-performing loans will still arise even though BRI Syari'ah Bank Mataram has conducted a rigorous analysis to select potential customers or debtors.

Customers (debtors) who experience non-performing loans at Bank BRI Syari'ah Mataram Branch are caused by several factors, namely First, debtors who do not have the will (not in good faith) to return the financing funds they have received. Second, debtors who do not have the ability to return the financing they have received, the debtor's inability occurs due to various factors such as bankruptcy due to decreased business and natural disasters such as floods, earthquakes and current covid. ${ }^{7}$ A debtor's inability to carry out his obligations is commonly referred to as a default debtor. Default is regulated in Article 1243 of the Civil Code, which can be concluded that, Default is an attitude in which a person does not fulfill or fails to carry out the obligations as specified in the contract or agreement made between the creditor and the debtor. Simply put, default is breaking promises or not keeping promises. ${ }^{8}$

Regarding non-performing loans, the Bank BRI Syari'ah Mataram Branch has its own way of resolution or operational standards that apply to the Mataram Branch of BRI Syari'ah Bank in handling non-performing

\footnotetext{
${ }^{1}$ Muhammad Djumhana, Hukum Perbankan Indonesia, PT Citra Aditya Bakti, Bandung, 2006, hlm. 552.

${ }^{2}$ Berdasarkan wawancara dengan Amirin, Account Officer NPF Bank BRI Syari'ah Cabang Mataram, tanggal 25 Januari 2021 , pukul 13.00 WITA.

${ }^{3}$ Berdasarkan wawancara dengan Amirin, Account Officer NPF Bank BRI Syari'ah Cabang Mataram, tanggal 25 Januari 2021, pukul 13.00 WITA.

${ }^{4}$ Sentosa, Hukum Perbankan, Cetakan Ke-1, CV Mandar Maju, Bandung, 2000, hlm. 68.

${ }^{5}$ Indonesia, Peraturan Bank Indonesia Nomor: 7/2/PBI/2005 Tentang Penilaian Kualitas Aktiva Bank Umum dan Lampiran I Surat Edaran Bank Indonesia No. 7/3/DPNP tanggal 31 Januari 2005 (LN No. 12 Tahun 2005, TLN No. 4471).

${ }^{6}$ Indonesia, Peraturan Bank Indonesia Nomor: 7/2/PBI/2005 Tentang Penilaian Kualitas Aktiva Bank Umum dan Lampiran I Surat Edaran Bank Indonesia No. 7/3/DPNP tanggal 31 Januari 2005 (LN No. 12 Tahun 2005, TLN No. 4471), Pasal 12 ayat (3).

${ }^{7}$ Berdasarkan wawancara dengan Amirin, Account Officer NPF Bank BRI Syari'ah Cabang Mataram, tanggal 25 Januari 2021, pukul 13.00 WITA.

${ }^{8}$ Indonesia, Kitab Undang-Undang Hukum Perdata, (Stbl. 1847-23), Pasal 1243.
} 
loans. ${ }^{1}$

Based on the results of the author's interview with the Bank BRI Syari'ah Mataram Branch, namely Amirin who was used as a resource in this study as the NPF Bank BRI Syari'ah Mataram Branch Account Officer on January 25, 2021 at 13.00 WITA at BRI Syari'ah Bank Mataram Branch, then in carrying out one of the tasks mandated by Law Number 4 of 1996 concerning Mortgage Rights in Article 6 Jo. Article 20 of Law Number 4 of 1996 concerning Mortgage Rights, the execution of mortgage rights at the Mataram Branch of BRI Syari'ah Bank is in accordance with the data and information that has been obtained by the author which will then be analyzed. The research results obtained are:

1. The settlement of non-performing loans is usually the creditor, in this case BRI Syari'ah Bank Mataram Branch, starting with the creditor to make a verbal warning / bill beforehand so that the debtor carries out his obligation, namely to return the financing funds he received in installments.

2. If when the creditor makes a verbal warning / bill it does not go well, then the Bank BRI Syari'ah Mataram Branch will issue a written notification / warning against the debtor by providing a Warning Letter (SP) which contains notification to the debtor regarding the fall. the due date of the refund, an order to make a certain refund in accordance with the request or notification of the Mataram Branch of the BRI Syari'ah Bank and notification of the guaranteed due mortgage object and payment limit.

3. Notice / warning will be made 3 (three) times in a period of 1 (one) consecutive week with the aim of asking for responsibility and good faith from the debtor in settling the obligation to return the financing fund that has been received.

4. If the debtor does not have good intentions to fulfill the refund obligation, usually the Mataram Branch of BRI Syari'ah Bank handles the settlement of non-performing loans through persuasive methods with a musyarawah approach to negotiate before in the end the Syari'ah Bank executes the object of the mortgage right. by auctioning through the KPKNL (Office of State Wealth and Auction Services). ${ }^{2}$

5. Negotiations can be carried out on debtors to settle their obligations and the method taken in this settlement is considered better than the settlement through litigation.

6. Settlement through negotiations within a period of 3 months, this is done so that the debtor has the opportunity to offer / sell the object of his own mortgage with the hope of getting a high price for the object of the mortgage so he can carry out a refund installment. ${ }^{3}$

7. This means that before the notification of the auction is issued, after the issuance of the SPI-SPII-SPIII, the Mataram Branch of the BRI Syari'ah Bank will continue to negotiate with the debtor, whether the object of the mortgage will be sold by the debtor within 3 months. in the hope of getting a high price. This step to rescue non-performing loans is called credit restructuring, which is a process to restructure nonperforming loans with the aim of improving the debtor's financial position.

8. However, if the restructuring effort does not produce results, then BRI Syari'ah Mataram Branch will adopt methods that are repressive in nature, namely through the paths that have been agreed upon in the contents of the contract and are determined by law.

9. Whereas because there is no longer good faith and cooperative attitude from debtors to settle their obligations and it is no longer possible for credit restructuring to be carried out, in an effort to get back the repayment of debtor non-performing loans, Bank BRI Syariah, Mataram Branch, as the holder of mortgage rights based on Article 6 Jo. Article 20 of Law Number 4 of 1996 concerning Mortgage Rights takes credit settlement efforts through the sale of collateral on one's own power (Parate Execution).

10. Then Bank BRI Syari'ah Mataram Branch conducted Parate Execution through a public auction or execution auction by submitting a written application for execution of mortgage rights to the State Wealth and Auction Service Office (KPKNL) assisted by BLS (Private Auction Hall). ${ }^{4}$

11. The procedure for carrying out the auction was preceded by the Bank BRI Syari'ah Mataram branch making and submitting an auction request letter to the local KPKNL to conduct an auction or sale in public, enclosing the following conditions: Copy of Mortgage Certificate; Copy of Financing Agreement; Copy of Debtor's Debt Recognition Deed; Copy of Somasi / Warning Letter to the debtor (last I, II and II); Copy of Proof of Payment of Land and Building Tax; Copy of Building Construction Permit; A copy of the debtor's KTP, the KTP of the Bank's Directors who signed the MOU with BLH; Copy of Notice of Tender to Occupants of the object of the Auction; Original Letter of Application for auction date to the Office of State Wealth and Auction Service (KPKNL); Original Letter of Attorney for Auction from the

\footnotetext{
${ }^{1}$ Berdasarkan wawancara dengan Amirin, Account Officer NPF Bank BRI Syari'ah Cabang Mataram, tanggal 25 Januari 2021, pukul 13.00 WITA.

${ }^{2}$ Berdasarkan wawancara dengan Amirin, Account Officer NPF Bank BRI Syari'ah Cabang Mataram, tanggal 25 Januari 2021 , pukul 13.00 WITA.

${ }^{3}$ Berdasarkan wawancara dengan Amirin, Account Officer NPF Bank BRI Syari'ah Cabang Mataram, tanggal 25 Januari 2021, pukul 13.00 WITA.

${ }^{4}$ Berdasarkan wawancara dengan Amirin, Account Officer NPF Bank BRI Syari'ah Cabang Mataram, tanggal 25 Januari 2021, pukul 13.00 WITA.
} 
Board of Directors of the Bank. Original Letter of details of the latest debts and all debtors' liabilities; Original Letter of Appointment of Selling Officer from the Bank; Original Letter of Auction Limit; Original Work Order Letter (SPK); Original Letter of Dispensation for Auction (if required); 2 (two) photographs as an example of the object to be auctioned; and Signing of the Principles of the Cooperation Agreement between the bank and the Auction House. ${ }^{1}$

12. Then the KPKNL will receive the auction request letter submitted by BRI Syari'ah Bank Mataram branch because it has been accompanied by the necessary letters and documents so that it has met the requirements for an auction. Furthermore ${ }^{2}$, the KPKNL made an auction schedule preceded by Announcement of Auction. ${ }^{3}$

13. Bank BRI Syari'ah Mataram Branch announced the auction through a template / leaflet at least 14 (fourteen) calendar days before the auction, this is the first announcement or what is commonly known as the First Auction. Furthermore, the Second Auction Announcement through the local daily newspaper / newspaper. For example, making the announcement of the Auction dated January 10, 2021 as the first announcement through leaflets and the announcement of the auction dated January 24, 2021 as the announcement of the second auction through the local daily newspaper. ${ }^{4}$ This is contained in Article 53 of the Minister of Finance Regulation Number 27 / PMK.06 / 2016 concerning Instructions for Implementation of Auctions.

14. The auction is conducted by the Auction Office which makes technical regulations on auction regulations. Tenders through KPKNL can be carried out continuously for a period of 3 (three) after the previous auction attempts have been carried out but there is no auction winner.

15. After the auction is carried out and obtaining the auction winner, the Bank BRI Syari'ah Mataram Branch will submit an application for vacating the auction object to the Religious Court and submit an application for removal and registration of the abolition of Mortgage Rights to the Land Office, this is carried out so that the auction winner can free from the mortgage that is imposed on the object of auction, in this case the object of mortgage is auctioned.

16. The auction office receives the proceeds from the sale of the auction winner, then the auction office submits it to the creditor, in this case the Bank BRI Syari'ah Mataram Branch, if there is any excess, the remainder is given to the debtor.

Based on the foregoing, it is clear that the steps to save non-performing loans carried out by the Mataram Branch of BRI Syari'ah Bank include credit restructuring, ${ }^{5}$ which is a process to restructure non-performing loans with the aim of improving the debtor's financial position through credit payments or refunds with terms that are more lenient or lighter than the terms of credit payments or refunds before the credit restructuring process is carried out. However, if there is no longer good faith and cooperative attitude from the debtor to settle their obligations and it is not possible for credit restructuring to be carried out, then in an effort to get back the repayment of the debtor's non-performing loans, Bank BRI Syariah Mataram Branch as the holder of the mortgage rights based on Law Number 4 of 1996 concerning Mortgage Rights taking efforts to resolve non-performing loans through the sale of collateral on their own power (Parate Execution).

Parate execution is the last resort made by the Mataram branch of BRI Syari'ah in handling non-performing loans as regulated in Article 20 of the Mortgage Law Number 4 of 1996 concerning Mortgage Rights, which states that:

(1) If the debtor breaches his / her promise, then based on:

a. The right of the first mortgage holder to sell the object of the mortgage as referred to in article 6;

b. Executive title contained in the certificate in the mortgage as referred to in Article 14 paragraph (2).

(2) Upon the agreement of the guarantor of the mortgage, the sale of the object of the mortgage can be carried out under the hand, if in this way the highest price will be obtained which will lead to all parties. ${ }^{6}$

As regulated under Article 6 of Law Number 4 of 1996 concerning Mortgage Rights, which states:

"If the debtor fails to promise, the holder of the first Mortgage has the right to sell the object of the Mortgage Rights at his own power through a public auction and collect the debt from the auction proceeds."7

Execution under Article 6 Jo. Article 20 Paragraph (1) Letter (a) The Mortgage Rights Law provides the

${ }^{1}$ Berdasarkan wawancara dengan Amirin, Account Officer NPF Bank BRI Syari'ah Cabang Mataram, tanggal 25 Januari 2021, pukul 13.00 WITA.

${ }^{2}$ Indonesia, Peraturan Menteri Keuangan Republik Indonesia Nomor 27/PMK.06/2016 tentang Petunjuk Pelaksanaan Lelang, Berita Negara Republik Indonesia Tahun 2016 Nomor 270, Pasal 13.

${ }^{3}$ Indonesia, Peraturan Menteri Keuangan Republik Indonesia Nomor 27/PMK.06/2016 tentang Petunjuk Pelaksanaan Lelang, Berita Negara Republik Indonesia Tahun 2016 Nomor 270, Pasal 1 ayat (1).

${ }^{4}$ Berdasarkan wawancara dengan Amirin, Account Officer NPF Bank BRI Syari’ah Cabang Mataram, tanggal 25 Januari 2021, pukul 13.00 WITA.

${ }^{5}$ Surat Edaran Bank Indonesia, SE BI No.26/4/BPPP, tanggal 29 Mei 1993.

${ }^{6}$ Indonesia, Undang-Undang Nomor 4 Tahun 1996 Tentang Hak Tanggungan, (LN No. 104 Tahun 1960, TLN No. 2043), Pasal 20.

${ }^{7}$ Indonesia, Undang-Undang Nomor 4 Tahun 1996 Tentang Hak Tanggungan, (LN No. 104 Tahun 1960, TLN No. 2043), Pasal 6. 
authority to carry out direct executions without the need to ask for a ruling or fiat execution from the court first. Such authority is seen as an execution right which is called Parate Execution (direct execution). This can be seen from the words selling on their own power, which indicates a position that is prioritized to the holder of the mortgage right, in this case the Mataram Branch of BRI Syari'ah Bank as the creditor. Direct execution which is usually also called parate execution (parate executie) is execution that can be carried out directly without court assistance. The authority to sell on their own power is strengthened by a promise in the Deed of Providing Mortgage Rights (APHT) which states that the holder of the first mortgage has the right to sell on his own power the object of the security right if the debtor fails to promise.

Bank BRI Syari'ah Mataram Branch submitted an auction application to the KPKNL, assisted by the BLS (Private Auction Hall) to determine the implementation of the auction. After the auction application is submitted by the Mataram Branch of BRI Syari'ah Bank which has been accompanied by the necessary letters and documents so that it has fulfilled the requirements for the auction, then based on Article 13 of the Minister of Finance Regulation Number 27 / PMK.06 / 2016 concerning Auction Implementation Instructions firmly stated that the Head of the KPKNL / Class II Auction Officer may not reject the auction application submitted to him as long as the auction is complete and has met the formal legality of the subject and object of the auction. ${ }^{1}$

The implementation of the execution auction carried out by the KPKNL (State Wealth and Auction Service Office) with the existence of the auction application submitted by the Mataram Branch of BRI Syari'ah Bank is in accordance with the Regulation of the Minister of Finance Number 27 / PMK.06 / 2016 concerning Guidelines for Auction Implementation, which states that KPKNL is a government agency under the Directorate General of State Assets at the Ministry of Finance that is tasked with holding auctions.

Based on the study of the above rules and the results of the author's interview with Amirin who was used as a resource in this study as the NPF Bank BRI Syari'ah Mataram Branch Account Officer on January 25, 2021 at 13.00 WITA at BRI Syari'ah Bank Mataram Branch, the authors analyzed and concluded that the implementation of salvaging non-performing loans through execution parates at the Mataram Branch of BRI Syari'ah Bank is in accordance with the theory of legal effectiveness and theory of legal certainty as well as the theory of legal protection where the parate of execution is carried out based on the procedures and provisions in force in Law Number 4 of 1996 concerning Mortgage runs effectively in accordance with applicable laws and regulations, both Law Number 4 of 1996 concerning Mortgage Rights and Regulation of the Minister of Finance Number 27 / PMK.06 / 2016 concerning Instructions for Implementation of Auctions and still not contradicting the principles of shari'ah as referred to in the Law ng Number 21 of 2008 concerning Sharia Banking has also been enhanced with the Compilation of Sharia Economic Laws as the legal basis for the execution of mortgage rights so that there is legal certainty for the execution of mortgage rights at BRI Syari'ah Bank Mataram Branch in order to protect the interests of the first mortgage holder according to the description of understanding mentioned above, that the authority to sell on his own power is obtained by the creditor or the holder of the first mortgage not solely because of an agreement, but also because the law stipulates it.

\section{B. THE COMPETENCE OF THE GIRI RELIGIOUS COURT IN THE SETTLEMENT OF DISPUTES OF LIABILITY RIGHTS EXECUTION AT BANK BRI SYARIA'AH, MATARAM BRANCH}

Although the Mataram Branch of the BRI Syari'ah Bank has its own efforts regarding salvage of non-performing loans, namely by executing the object of the mortgage right by parate execution in accordance with the procedure as stipulated in Article 6 Jo. Article 20 paragraph (1) letter (a) of Law Number 4 of 1996 concerning Mortgage Rights. However, it does not rule out the possibility of a lawsuit being filed at the Religious Court. In the practice of conducting the auction for the execution of mortgage rights by the Mataram Branch of the BRI Syari'ah Bank through the KPKNL, there are often complaints from debtors and other parties who feel that their interests are being harmed. Civil lawsuits are usually in the form of challenges before the auction or claims that are filed after the auction ${ }^{2}$ This means that there is no good faith from the debtor, namely there is an element of unlawful action which results in the Mataram Branch of BRI Syari'ah Bank as a creditor unable to carry out the auction properly and will cause losses for the Bank BRI Syari'ah Mataram Branch, so in this case it is needed. institutions that are more credible to resolve these problems, namely through the judiciary in particular through the Religious Courts. A lawsuit can be submitted to the Religious Court on the grounds that the lawsuit includes, among others, an act against the law (PMH).

Because of the above, the Mataram Branch of BRI Syari'ah Bank as the creditor filed a lawsuit at the Giri Menang Religious Court because the object of the debtor's collateral was located in the jurisdiction of the Giri Menang Religious Court. This is in accordance with Article 55 paragraph (1) of Law Number 21 of 2008 concerning Islamic Banking which states:

\footnotetext{
${ }^{1}$ Indonesia, Peraturan Menteri Keuangan Republik Indonesia Nomor 27/PMK.06/2016 tentang Petunjuk Pelaksanaan Lelang, Berita Negara Republik Indonesia Tahun 2016 Nomor 270, Pasal 13.

${ }^{2}$ Berdasarkan wawancara dengan Amirin, Account Officer NPF Bank BRI Syari'ah Cabang Mataram, tanggal 25 Januari 2021 , pukul 13.00 WITA.
} 
"The settlement of Sharia Banking disputes is carried out by courts within the Religious Courts". ${ }^{1}$

Bank BRI Syari'ah Mataram Branch submitted an Application for the Execution of Mortgage Rights to the Giri Menang Religious Court Number B.066 / KC Mataram / 01/2019 dated January 7, 2019 with the contents of the application, namely the Aanmaning Request, Execution Seizure and Guarantee Auction. ${ }^{2}$

Apart from the aforementioned matters, the execution of the parate of mortgage rights sometimes becomes unclear. One of this can be seen in Article 14 paragraph (2) and (3) of Law Number 4 of 1996 concerning Mortgage Rights, where execution can be carried out on a certificate of mortgage which contains irah-irah with the words: "DEMI JUSTICE BASED ON ONE ALMIGHTY GOD ". Thus, irah-irah shows that the execution of the object of collateral over land bound by mortgage is understood as the execution as the gross acte Hypotheek. In addition, in the general explanation Number 9 of Law Number 4 of 1996 concerning Mortgage Rights, it is stated that the concept of Parate for Mortgage Execution as referred to in Article 14 paragraph (3) of Law Number 4 of 1996 concerning Mortgage Rights still refers to Article 224 Herziene. Indonesisch (hereinafter abbreviated as HIR). This condition causes multiple interpretations that do not contradict Article 6 Jo. Article 20 paragraph (1) letter (a) of the Mortgage Rights Law, Article 14 paragraph (3), and Number 9 General Elucidation of Law Number 4 of 1996 concerning Mortgage Rights. This condition ultimately makes the principle of convenience and legal certainty for parate execution of mortgage rights not achieved, because in the end the creditors, in this case the mortgage holder, cannot carry out the execution of the mortgage easily in accordance with the purpose of the establishment of the Mortgage Rights Law as stated in the General Explanation Law Number 4 of 1996 concerning Mortgage Rights, because it continues to go through a court process.

The mandatory execution parate through the court is further strengthened by the Supreme Court Circular (SEMA) Number 7 of 2012 number XIII from the Sub-Chamber of General Civil, which states that:

"Auction of Mortgage which is carried out by the creditors themselves through the auction office, if the auctioneer does not want to vacate the object being auctioned, it cannot be vacated based on Article 200 paragraph (11) of the HIR, but a lawsuit must be filed. Because the auction mentioned above is not an execution auction but a voluntary auction "3

However, the results of the plenary of the room have been revised so that it reads as follows:

"With respect to the auction of mortgage rights by the creditor himself through the auction office, if the auctioneer does not want to vacate the auction object, the execution of blanking can be submitted directly to the Chairman of the court without going through a lawsuit". ${ }^{4}$

Referring to the Supreme Court Circular (SEMA) Number 7 of 2012 number XIII from the General Civil Service Sub-Chamber, the safest attitude for creditors, in this case BRI Syari'ah Bank Mataram Branch, is to carry out mortgage execution through the Religious Court until the object is empty Mortgage rights because creditors, in this case BRI Syari'ah Bank Mataram Branch, are not entitled to vacate the object of the mortgage so there is no need to work twice if later problems arise during the auction and vacating. So it can be concluded that Bank Syari'ah, in this case BRI Syari'ah Bank Mataram branch, can only carry out the auction, because vacating the object of mortgage is the authority of the Religious Court.

The Religious Court is one of the special courts within the jurisdiction of the judiciary in Indonesia based on the provisions of statutory regulations, namely Law Number 14 of 1970 concerning Basic Provisions of Judicial power which has been renewed by Law with Law Number 4 of 2004 and Law Number 48 of 2009 concerning Judicial Power, Law Number 7 of 1989 which has been amended by Law Number 50 of 2009 concerning the Religious Courts. The existence of a Religious Court which is a state court, is intended for people who are Muslim. The Religious Courts have the duty and authority to examine, decide and settle cases at the first level between people who are Muslim in the fields of: marriage, inheritance, infaq, shadaqah, and resolving disputes over zakat, as well as wills, other civil and shari'ah economics. ${ }^{5}$

However, there is another problem that then arises, namely the existence of a forum as contained in the Elucidation of Article 55 paragraph (2) of Law Number 21 of 2008 concerning Islamic Banking, which states that dispute resolution is carried out in accordance with the contents of the Akad is an effort of deliberation banking mediation, through the National Syari'ah Arbitration Board (Basyarnas) or other arbitration institutions, and / or through courts within the General Courts ${ }^{6}$ The elucidation of Article 55 paragraph (2) of Law Number

\footnotetext{
${ }^{1}$ Indonesia, Undang-Undang Nomor 21 Tahun 2008 tentang Perbankan Syari'ah, (LN No. 182 Tahun 1998, TLN No. 3790), Pasal 55 ayat (1).

${ }^{2}$ Berdasarkan wawancara dengan Amirin, Account Officer NPF Bank BRI Syari'ah Cabang Mataram, tanggal 25 Januari 2021, pukul 13.00 WITA

${ }^{3}$ Surat Edaran Mahkamah Agung Nomor 7 Tahun 2012, 10/BUA.6/HS/SP/IX/2012, tanggal 8 Maret 2012-5 Mei 2012, angka XIII dari Sub Kamar Perdata Umum.

${ }^{4}$ Surat Edaran Mahkamah Agung Nomor 7 Tahun 2012, 10/BUA.6/HS/SP/IX/2012, tanggal 8 Maret 2012-5 Mei 2012, angka XIII dari Sub Kamar Perdata Umum.

${ }^{5}$ Indonesia, Undang-Undang Nomor 3 Tahun 2006 tentang Perubahan Atas Undang-Undang Nomor 7 Tahun 1989 tentang Peradilan Agama, (LN No. 9 Tahun 2004, TLN No. 4359), Pasal 49.

${ }^{6}$ Indonesia, Undang-Undang Nomor 21 Tahun 2008 tentang Perbankan Syariah, (LN No. 182 Tahun 1998, TLN No. 3790), Penjelasan
} 
21 of 2008 concerning Syari'ah Banking can create legal uncertainty that can cause losses for parties, namely the customer (debtor) and the Syari'ah Bank (creditor).

Based on the elucidation of Article 55 paragraph (2) of Law Number 21 of 2008 concerning Islamic Banking, there is a choice of forum for resolving shari'ah economic disputes, resulting in overlapping authority to adjudicate shari'ah economic disputes considering that there are 2 (two) judicial institutions that are given the authority to resolve shari'ah economic disputes, the Religious Courts and the General Courts.

According to Fathur Rahman as the Young Primary Judge of the Giri Menang Religious Court who was a resource in this study, stated that the Religious Court has absolute authority in handling shari'ah economic cases as long as in its contract the forum for dispute resolution chosen is the Religious Court, this is in effect since the issuance of the Constitutional Court Decision Number 93 of $2012^{1}$. This means that before the issuance of the Constitutional Court Decision Number 93 of 2012, the litigants can choose to resolve disputes within the Agma or Judiciary or Basyarnas courts, but with the issuance of the Constitutional Court Decision Number 93 of the Year. 2012 there was a change so that the alternative option was eliminated.

With the issuance of the Constitutional Court Decision Number 93 of 2012 which states that the explanation for Article 55 paragraph (2) of Law Number 21 of 2008 concerning Sharia Banking is contrary to the 1945 Constitution of the Republic of Indonesia, this explanation is null and void by law and no longer has binding strength $^{2}$. In the verdict of the Constitutional Court Panel of Judges, it is stated that the Elucidation of Article 55 paragraph (2) of Law Number 21 of 2008 concerning Sharia Banking is contrary to the 1945 Constitution of the Republic of Indonesia and has no binding legal force. The verdict of the Panel of Judges of the Constitutional Court Number 93 of 2012 can be identified as a decision that is declaratory and constitutive in nature ${ }^{3}$, because the decision contains a statement and does not contain elements of condemnation and the decision negates a legal condition or creates a new legal state. ${ }^{4}$

The legal implication of the decision of the Constitutional Court provides confirmation that the Elucidation of Article 55 paragraph (2) of Law Number 21 of 2008 concerning Islamic Banking does not have binding legal force so that a legal condition described in the explanation of the article is lost and null and void by law. Cancellation of Elucidation of Article 55 paragraph (2) of Law Number 21 of 2008 concerning Sharia Banking does not automatically cancel Article 55 paragraph (2) of Law Number 21 of 2008 concerning Islamic Banking. In this case, it is very clear that what is declared contrary to the 1945 Constitution of the Republic of Indonesia and does not have binding legal force is the explanatory text.

Normatively, the Constitutional Court Decision Number 93 of 2012 affirms that the settlement of shari'ah banking disputes is the absolute authority of the court within the Religious Courts as mandated by Article 49 letter (i) of Law Number 3 of 2006 concerning Amendments to Law Law Number 7 of 1989 concerning Religious Courts. The authority of the Religious Courts prior to the enactment of Law Number 3 of 2006 as stipulated in Article 49 of Law Number 7 of 1989 which is clarified in the General Explanation of number (2) third paragraph of Law Number 7 of 1989 covers the fields of marriage, inheritance, will and grants, which are carried out based on Islamic law as well as waqaf and shadaqah. ${ }^{5}$

Based on the results of the author's interview with the Giri Menang Religious Court, namely with Fathur Rahman as the Young Primary Judge of the Giri Menang Religious Court on January 25, 2021 at 09.00 WITA at the Giri Menang Religious Court in West Lombok and research on the laws and regulations related to this research as The author has described above, in fact it is quite clear that the authority of the Religious Courts has been regulated in Law Number 3 of 2006 concerning Amendments to Law Number 7 of 1989 concerning the Religious Courts. Thus, the settlement of mortgage execution disputes at Bank BRI Syari'ah Mataram branch has become the competence of the Giri Menang Religious Court and cannot be examined by any other court body as long as the litigant includes it in its contract and submits an application to the Giri Menang Religious Court. Although the parties are given the freedom to determine the dispute settlement mechanism, the settlement process is still based on the principles of syari'ah as stipulated in Article 55 paragraph (3) of Law Number 21 of 2008 concerning Islamic Banking. This is based on the fact that the legal relationship that occurs between legal subjects is based on the principles of syari'ah, so it will give birth to legal consequences, of course, the settlement process is also based on the principles of syari'ah. Meanwhile, the only courts that are able to apply sharia principles and make the Al-Qur'an, Hadith Rasul, and ijtihad of Islamic jurists as guidelines for proceeding in the judiciary are only the Religious Courts. According to the author, the competence of the Giri Menang Religious

Pasal 55 ayat (2)

${ }^{1}$ Berdasarkan wawancara dengan Fathur Rahman, Hakim Pratama Muda Pengadilan Agama Giri Menang, tanggal 25 Januari 2021 , pukul 09.00 WITA.

${ }^{2}$ Oyo S. Mukhlas, Dual Banking System \& Penyelesaian Sengketa Ekonomi Syariah, Cetakan Kesatu, PT Refika Aditama, Bandung, 2019, hlm. 120 .

${ }^{3}$ Ibid, hlm. 125

${ }^{4}$ Maruarar Siahaan, Hukum Acara Mahkamah Konstitusi Republik Indonesia, Edisi 2, Sinar Grafika, Jakarta, 2012 , hlm. 206.

${ }^{5}$ Oyo Sunaryo Mukhlas, Perkembangan Peradilan Islam: dan Kahin di Jazirah Arab ke Peradilan Agama di Indonesia, Ghalia Indoneisa, Jakarta, 2011, hlm. 101. 
Court in resolving shari'ah economic disputes at the Mataram Branch of the BRI Syari'ah Bank has become the absolute competence (authority) of the Religious Courts regarding marriage, inheritance, waqf, zakat is a necessity, this is in accordance with the theory of legal certainty and the theory of authority that the Religious Courts in this case the Giri Menang Religious Courts have absolute competence (authority) in handling shari'ah economic cases because the choice of forum for resolving shari'ah economic disputes is eliminated with the issuance of the Constitutional Court Decision Number 93 of 2012. Thus, the Constitutional Court decision has confirmed and strengthened that shari'ah economic disputes are under the authority of the Religious Courts and have guaranteed legal certainty in their implementation.

\section{CONCLUSION}

1. The implementation mechanism for the execution of mortgage rights at the Bank BRI Syari'ah Mataram branch is the Parate Executie. Where in the execution of the mortgage rights execution runs effectively based on Article 6 Jo. Article 20 of Law Number 4 of 1996 concerning Mortgage Rights so that there is legal certainty for the implementation of the execution of mortgage rights at the Mataram Branch of BRI Syari'ah Bank in order to protect the interests of the first Mortgage holder. It's just that, the convenience provided by the Mortgage Rights Law is in fact the creditor can only carry out the auction without vacating which is based on the Supreme Court Circular Letter Number 7 of 2012 which states that the blanking of the object of the mortgage can only be done by the Religious Court and if any resistance when the execution of the execution parate must be resolved through the Religious Court, this can result in the creditor being unable to carry out the execution of mortgage relatively easily and quickly in accordance with the purpose of the establishment of Law Number 4 of 1996 concerning Mortgage Rights.

2. Settlement of Mortgage Execution Dispute at Bank BRI Syari'ah Mataram branch has become the absolute competence (authority) of the Giri Menang Religious Court as long as this is stated in the contract. Regarding the competence of the Giri Menang Religious Court in resolving execution disputes at the Mataram Branch of BRI Syari'ah Bank which is based on Article 49 of Law Number 3 of 2006 concerning Amendments to Law Number 7 of 1989 concerning Religious Courts and Article 55 of Law Number 21 Year 2008 concerning Sharia Banking which states that the settlement of Sharia Banking disputes is carried out by a court within the Religious Courts and the choice of forum for dispute resolution (choice of forum) which is eliminated with the issuance of the Constitutional Court Decision Number 93 of 2012.

\section{REFFERENCES}

BOOK

Adrian Sutedi, Hukum Hak Tanggungan, Sinar Grafika, Jakarta, 2010.

Faturrahman Djamil, Penyelesaian Pembiayaan Bermasalah di Bank Syariah, Sinar Grafika, Jakarta, 2012.

Maruarar Siahaan, Hukum Acara Mahkamah Konstitusi Republik Indonesia, Edisi 2, Sinar Grafika, Jakarta, 2012. Muhammad Djumhana, Hukum Perbankan Indonesia, PT Citra Aditya Bakti, Bandung, 2006.

Oyo S. Mukhlas, Dual Banking System \& Penyelesaian Sengketa Ekonomi Syariah, Cetakan Kesatu, PT Refika Aditama, Bandung, 2019.

, Perkembangan Peradilan Islam: dan Kahin di Jazirah Arab ke Peradilan Agama di Indonesia, Ghalia Indoneisa, Jakarta, 2011.

Sentosa, Hukum Perbankan, Cetakan Ke-1, CV Mandar Maju, Bandung, 2000.

\section{ARTICLES AND JOURNALS}

Nurma Khusna Khanifa, "Jaminan Akad Murabahah di Lembaga Keungan Syariah Kajian Hukum Perdata”, Az-Zarqa', Volume 7 No. 2, Desember 2015, Purwokerto.

\section{REGULATIONS}

Dewan Syari'ah Nasional MUI, Himpunan Dewan Syari'ah Nasional MUI, Nomor 10/18/DSN-MUI/II/2005 tentang Penjadwalan Kembali Tagihan Murabahah.

Indonesia, Kitab Undang-Undang Hukum Perdata, (Stbl. 1847-23).

Indonesia, Undang-Undang Nomor 3 Tahun 2006 tentang Perubahan Atas Undang-Undang Nomor 7 Tahun 1989 tentang Peradilan Agama, (LN No. 9 Tahun 2004, TLN No. 4359).

Indonesia, Undang-Undang Nomor 4 Tahun 1996 tentang Hak Tanggungan, (LN No. 104 Tahun 1960, TLN No. 2043).

Indonesia, Undang-Undang Nomor 21 Tahun 2008 tentang Perbankan Syariah, (LN No. 182 Tahun 1998, TLN No. 3790).

Indonesia, Peraturan Bank Indonesia Nomor: 7/2/PBI/2005 Tentang Penilaian Kualitas Aktiva Bank Umum dan Lampiran I Surat Edaran Bank Indonesia No. 7/3/DPNP tanggal 31 Januari 2005, (LN No. 12 Tahun 2005, TLN No. 4471). 
Indonesia, Peraturan Menteri Keuangan Republik Indonesia Nomor 27/PMK.06/2016 tentang Petunjuk Pelaksanaan Lelang, Berita Negara Republik Indonesia Tahun 2016 Nomor 270.

Surat Edaran Bank Indonesia, SE BI No.26/4/BPPP, tanggal 29 Mei 1993.

Surat Edaran Mahkamah Agung Nomor 7 Tahun 2012, 10/BUA.6/HS/SP/IX/2012, tanggal 8 Maret 2012-5 Mei 2012.

\section{INTERVIEW}

Amirin, Account Officer NPF Bank BRI Syari'ah Cabang Mataram, tanggal 25 Januari 2021, pukul 13.00 WITA. Fathur Rahman, Hakim Pratama Muda Pengadilan Agama Giri Menang, tanggal 25 Januari 2021, pukul 09.00 WITA. 